\title{
The Effect of Transformational Leadership on Market Orientation, Learning Orientation, Organization Innovation and Organization Performance (Study on Star-Rated Hotels in Central Java Province, Indonesia)
}

\author{
Widiartanto ${ }^{1}$, Suhadak ${ }^{2}$ \\ ${ }^{1}$ Department of Business Administration, University of Diponegoro, Semarang, Indonesia \\ ${ }^{2}$ Department of Business Administration, University of Brawijaya, Malang, Indonesia
}

\begin{abstract}
The study is aimed at examining the Effect of Transformational Leadership on Market Orientation, Learning Orientation, Organization Innovation and Organization Performance of the Star-Rated Hotels in Central Java Province. The research samples cover 110 Marketing Managers of the Star-Rated Hotels in Central Java Province. Sample determination applies totals sampling or population sampling in which all members of the population are used as research samples and its Marketing Manager as the respondent represents every star-rated organization/hotel. In examining the established model relationship, the data are analyzed by using Structural Equation Modeling (SEM). The results reveal: Transformational Leadership does not give significant effect on Organization Performance; Transformational Leadership gives significant effect on Market Orientation; Transformational Leadership gives significant effect on Organization Innovation; Transformational Leadership gives significant effect on Learning Orientation; Market Orientation does not give significant effect on Organization Performance; Market Orientation gives significant effect on Organization Innovation; Market Orientation does not give significant effect on Learning Orientation; Learning Orientation gives significant effect on Organization Innovation; Learning Orientation does not give significant effect on Organization Performance; and Organization Innovation gives significant effect on Organization Performance.

The findings of this study are in line with Resources Based approach and Organizational Learning Theory as well, meaning both approaches work synergistically in providing research model used in the starrated hotels in Central Java Province. It is evident that learning orientation variables give direct significant effect on organization innovation and they give significant effect on organization performance through organization innovation variables as mediating variables. The indicators showing the most dominant contribution on research variables involve demonstrating acknowledgement towards Transformational Leadership, market survey on Market Orientation, self-correction by exchanging ideas and identifying environment on Learning Orientation, improving work practices for Organization Innovation and escalating market share for Organization Performance.
\end{abstract}

Keywords: Transformational Leadership, Market Orientation, Learning Orientation, Organization Innovation and Organization Performance

\section{Introduction}

The background of the study lies on the facts that there are several research gaps, among others, the differences of the research results regarding the effect of leadership on organization performance as stated by Kazt and Kahn (1978) and Peters and Waterman (1982) in Yukl (2009) shows that leadership gives positive significant effect on organization performance. Meanwhile, Meindl et al. (1985) and Pfefer (1977) in Yukl (2009) state that leadership does not give positive significant effect on organization performance. The next gap is the contradictive research results relating to the effect of market orientation on organization performance. Researchers such as Castro et al. (2005), Kirca et al. (2005) and Jain and Bhutia (2007) conclude that market orientation has a positive significant effect on organization performance. On the other hand, some researchers suggest different result that market orientation does not give positive significant effect on organization performance (Jaworski and kohli, 1993; Selnes et al., 1996; Pelham, 1997; Deshpande et al., 2000; and Harris, 2001).

On the effect of market orientation on organization innovation, the research result also reveals differences. Some researchers convince that market orientation gives positive significant effect on organization innovation (Han et al., 1998; Vasques et al., 2001; Agarwal et al., 2003; Kirca, 2005; Mavondo et al., 2005; and Tajeddini et al., 2006). However, Lawton and Parasuraman (1980), Lukas and Ferrell (2000), Verhees (2004), and Kurtinainitiene (2005) state that market orientation does not give positive significant effect on organization innovation. Further, another different research result is found in the effect of organization 
innovation on organization performance as proposed by Agarwal et al. (2003) and Im and Workman (2004). Their findings show that organization innovation gives positive significant effect on organization performance. Yet, Mavondo et al. (2005) and Darroch (2005) explain that organization innovation does not give positive significant effect on organization performance.

Besides those research gap above, the study is motivated by several business phenomena, such as the development of global tourism trend with innovation as the keyword. In fact, there are only a few researches that specifically examine the new trend in global tourism and its impact. According to Damanik (2011), one of the strategic study themes is the shift in the socio-economic profile of tourists marked by, among others, their high mobility from one destination to another, the increasing proportion of the elderly yet dominated by babyboomer, and high involvement of middle-class in the touris markets that have strong implications on the changes in travel management. On the practical level, the ways of handling them are different from handling conventional tourists. Here, innovation is the key word - the introduction of new ideas, new products, new designs and many others (Page, 2007).

Another interesting phenomenon that influences the hospitality industry in Indonesia is the rapid growth of MICE industry (Meeting, Incentive, Convention, and Exhibition) which is also known as "The Meeting Industry". The term MICE in Indonesia is also known as convention tourism. The convention tourism is part of tourism activities since a lot of tourism facilities are used in its implementation, therefore, it is categorized as labor-intensive activity that gives great contribution to both labor supply and state revenues. Based on the data acquired from ICCA Statistics Report (2010), the venues held for MICE activities are mostly located in hotel reaching $43 \%$, conference/exhibition hall $26 \%$, universities $21.1 \%$ and others $9.5 \%$.

Recently, world tourism has grown rapidly that tourism industry becomes a profitable business area, further it encourages some improvements in economic sector. Indonesia as one of the world's leading tourist destinations with beautiful islands scattered throughout the archipelago also acquaires the benefit of the development of tourism sector in the world. During the period of 2010 to the mid of 2011, there was an increase of $6.50 \%$ in the number of foreign tourists visiting Indonesia through 19 main entrances.

Among the nineteen (19) main entrances for foreign visitors to enter Indonesia, there are two important main entrances to Central Java Province and Special District of Yogyakarta-Adisumarmo Airport in Solo and Adi Sucipto Airport in Yogyakarta. Both airports are widely used by foreign tourists when they visit Central Java and Yogyakarta. Tourists usually go to Borobudur Temple, Prambanan Temple, Solo Palace, Yogyakarta Palace, Dieng Plateau and many others. During the period of $2010-2011$, there was an increase of $11.01 \%$ of the visitors coming through Adi Sumarmo Airport and an increase of 3.17\% of the visitors coming through Adi Sucipto Airport.

Referring to the previous study and the phenomenon of tight competition in hospitality industry, hence, the researcher is interested in analyzing the Effect of Transformational Leadership on Market Orientation, Learning Orientation, Organization Innovation and Organization Performance in Star-Rated Hotels in Central Java Province.

\section{Theoretical Review}

Regarding the definition of leadership, Yukl (2009) cites from some definitions proposed by experts in leadership and eventually concludes that leadership involves the process of social influence deliberately performed by a person towards another person to structure activities and relationship within an organization. The differences over those definitions lie on - who use the influence, how to use the influence, what target is going to be achieved from such influence and the result of the efforts in using such influence. Contemporary leadership concept assumes that leadership is a reciprocal process of disseminating influence to achieve a common goal (Lussier and Achua, 2001). One of the theories that emphasize the most comprehensive change in leadership is the theory of transactional and transformational leadership (Bass and Avolio, 1993). The initial idea of transactional and transformational leadership style was developed by James MacGregor Burns who applied it in political context. Further, the idea was complemented and introduced in the organizational context by Bernard Bass (Bass and Avolio, 1993).

According to Burns in Elencov (2002), the transformational leadership will lead its followers to experience trust, admiration, loyalty and respect towards their leader, thus, the followers are motivated to make a greter effort than what the leader has previously expected (Yukl, 2009). Transformational leadership involves several aspects such as values, trust, integrity, fairness, ethics, vision, charisma, agents of change, communication, goals and standards (Avolio and Bass, 2002). Burns (1978) defines transformational leadership as a process to elevate the morality and motivation of the leaders and subordinates to a higher level. Transformational leader tries to enhance the awareness of the subordinates by promoting higher idealism and moral values like freedom, justice, peace, balance, humane, and not be based on emotional circumstances like fear, greed, jealousy, and hatred. 
According to Lukas \& Ferel (2000), market orientation is defined as the process of creating and delivering market information to construct superior value for consumer. Meanwhile, Narver and Slater (1990) explain that market orientation is a concept focussing on constructing high values for consumer. Although there are various terms on market orientation, yet the four experts giving important contribution on the development of the concept are Kohli and Jaworski and Narver and Slater. According to Kohli and Jaworski (1990a), market orientation is "organization wide generation of market intelligence pertaining to current and future customer needs, dissemination of the intelligence across departments, and organization wide responsiveness to it."

Garvin (1993) defines organizational learning as a process in which the company learns to have such expertise in creating, learning and transferring knowledge as well as attitude of the company to reflect the company's learning outcomes. Schwandt (1993) defines organizational learning as a system of action, actor, symbol and process enabling an organization to transform information into valuable knowledge that can be used by an organization to improve its long-term adaptive capacity. Lukas, et al. (1996) in Farrel (2000) states that organizational learning is considered as the key to success for organization in the future. This concept is different from neoclassic theory arguing that assets, land, labor and capital are the key elements of productivity. Hunt \& Morgan (1995) also state that information and knowledge are the key elements for success. Meanwhile, Stata (1989) explains that learning orientation is a process in which individuals acquire new knowledge and insight that further modify their behavior and attitudes.

Damanpour (1991) distinguishes three concepts of innovation in relation to organization; organizational innovation, innovativeness and capacity to innovate. The innovativeness is defined as level in which an individual or unit relatively adopt new ideas earlier than other members of the organization system do (Avlonitis et al., 1994). Further, Hurley and Hult (1998) explain that the innovativeness is more like organizational culture aspects reflecting the level of openness towards new ideas. On the other hand, the capacity to innovate is considered as the organizational ability to adopt or implement new ideas, process and new products. Hurley and Hult (1998) adapt these two concepts in his research model, and identify them as organizational culture, while the capacity to innovate as organization performance. Organizational innovation is defined as the adoption of new ideas or behavior within an organization (Damanpour, 1991). Innovation involves all dimensions of organization activities; like new products and services or new production process technology, structure and new administrative system, or planning or new program within an organization.

Organization performance is the parameter of success in an organization, which is measured periodically. The result can be considered as the value of every arranged and implemented activity in order to identify whether the strategy that has been developed and implemented works appropriately or even inappropriately. Pelham \& Wilson (1996) define organization performance as the success of having new product and great market development in which company performance is measured through sales growth and market share.

\section{The Effect of Transformational Leadership on Market Orientation, Learning Orientation, Organization Innovation and Organization Performance}

The theory applied in the study of the effect of transformational leadership on organization performance is the theory of transformational versus transactional leadership. The theory suggests that the role of a leader in achieving organization compertence has been defined in a knowledge-based theory; the use of transformational leadership can improve organization performance.

Furthermore, the theory applied in the effect of transformational leadership on market orientation is market orientation theory. The theory suggests that the development of market orientation within a company is not merely a simple matter. According to Siguaw et al. (1998), there are several constraints in the implementation of market orientation; one of them is the corporate culture that long has been well established in a company. In their study, Jaworski and Kohli (1993) reveal that additional factor is required in order to be able to implement and develop market orientation in a company. In the context of marketing, when a company is ready to direct its business into a market-oriented business; thus, leadership style is a critical factor that determines the success of market oriented implementation in a company (Harris and Ogbonna, 2001). It happens because leadership is indeed highly influential in the life of a company as a whole, including the creation of a conducive atmosphere in the company for the growth of marketing culture.

The theory used in analyzing the effect of transformational leadership on organization innovation is transformational versus transactional leadership theory. The theory explains that promoting organization innovation requires transformational leadership to face the new economic era based on intellectual capital. Transformative leadership enables an organization to learn and innovate through experiments - dialogue self-control— broad knowledge about organization (Senge et al., 1994).

The theory used in analyzing the effect of transformational leadership on learning orientation is transformational versus transactional leadership theory. The theory explains that a transformative leader will become a catalyst / mentor / facilitator / trainer in his/her learning capability. Organizational learning happens 
when managers do not only generate ideas but also have the ability to share ideas and reach a commitment to learn among the members (Ulrich et al., 1993.). A leader who does not have a commitment to learn will trigger a wave of organizational cynicism (Maani and Benton, 1999).

The theory used in analyzing the effect of market orientation on organization performance is market orientation theory. Market orientation provides the company with "the focus on the efforts and activities of both individual and department in an organization to achieve excellent performance" (Kohli and Jaworski, 1990). In addition, market orientation is also used to obtain information on market demand and to adjust the decisionmaking based on market information. Consequently, the company needs to adjust market demand so that customers' satisfaction and loyalty can be improved (Kohli and Jaworski, 1990). The concept is in line with the findings dicovered by the writer in which market orientation has direct, positive and significant impact towards performance. The theory used in analysing the effect of market orientation on organization innovation is market orientation theory. The elements of market orientation have long been associated with innovation in some researchs. (eg, Agarwal et al., 2003; Han et al., 1998; Hult et al., 2004, Sandvik and Sandvik, 2003). Firstly, market orientation has contributed access to new ideas from the market and encouraged the company to fulfil the demand (Lucas and Ferrell, 2000). Secondly, strong market orientation reflects comprehensive understanding upon customer needs and competitive situation (Salavou et al., 2004). Thirdly, market orientation increases the possibility of having a better innovation based on the market needs, and therefore, it increases the confidence of the company to use innovation as a managerial activity (Gatignon and Xuereb, 1997). Finally, market orientation creates an environment that facilitates organizational innovation (Damanpour, 1991).

The theory used in the study of the effect of market orientation on learning orientation is market orientation theory. Day (1994) explains that market orientation can be fostered by "studying and learning" about market. The view leads to a debate over the causality between learning orientation and market orientation. However, Bell et al. (2002) tries to reconcile those different views by stating, "Both learning orientation and market orientation in an organization are mutually dependent." We find that the relationship among learning orientation, market orientation and innovation lies on the continuum of exploitation - exploration. Learning orientation is about exploration and innovation is about exploitation, while market orientation stands in the middle of both characteristics.

The theory applied in the study of the effect of learning orientation on organization innovation is organizational learning theory. An organization can adapt as long as they can learn. Consequently, the fact that learning is primarily concerned with sustainable organizational issues and the use of knowledge in an uncertain competitive atmosphere (Morgan and Strong, 1997), has initiated a more convincing concept stating that effective learning orientation deals with innovation. Indeed, Hurley and Hult (1998) propose evidences to show that higher level of innovation is associated with the development of culture of learning.

The theory used in the study of the effect of learning orientation on organization performance is organizational learning theory. Several empirical studies have demonstrated a positive relationship between organizational learning and organization performance (Bontis et al., 2002; Ellinger et al., 2002; Tippins and Sohi, 2003). The efforts to relate learning orientation and organizational performance in general reveal that an organization having higher level of learning mostly outperform their competitors, particularly in a chaotic and competitive environment (Dickson, 1992; DeGeus, 1988).

The theory used in analyzing the effect of organization innovation on organization performance is organization innovation theory. Although there are some contradictory evidences (Armour and Teece, 1978; Hage and Aiken, 1967; Kimberly and Evanisko, 1981; Rogers, 1995), most studies have shown the positive effect of innovation on performance (Bierly and Chakrabarti, 1996; Brown and Eisenhard, 1995; Cave and Ghemawat, 1992; Damanpour and Evan, 1984; Damanpour et al., 1989; Hansen et al., 1999; Roberts, 1999; Wheelwright and Clark, 1992; Schulz and Jobe, 2001. Shortly, both theory and empirical studies show a positive relationship between innovative activity and company performance.

\section{Method}

The research is conducted on 110 star-rated hotels in Central Java Province as the unit of analysis spread over 25 (twenty-five) districts/municipalities. The variable data of Transformational Leadership, Market Orientation, Learning Orientation, Organization Innovation and Organization Performance are primary data collected through questionnaires and interviews. The activities of collecting data were conducted in 6 (six) months, from January to June 2011.

Based on the sampling technique applied, totals sampling or population sampling, all members of the population are used as research samples and its Marketing Manager as the respondent represents every star-rated organization/hotel. Based on the existing data, there are 118 star-rated hotels in Central Java Province in 2011. At the time of data collection, 8 (eight) star-rated hotels could not be observed in order to obtain the primary data. They had their own reasons, as follows; one hotel was in the process of merger, another one did not want to fill out the questionnaire because of the confidentiality reason, three hotels were closed and three other hotels 
were sold and had been inactive for almost 2 years. Thus, the total number of the research samples is 110 questionnaires that will be analyzed and processed in the study.

To describe the variables of Transformational Leadership, Market Orientation, Learning Orientation, Organization Innovation and Organization Performance, Descriptive Statistical Method is used. Meanwhile, SEM Method is used to examine and analyse the inter-effect of the variables, and test- $t$ is used to examine research hypotheses.

\section{Conceptual Framework And Hypotheses}

The hypotheses model of this research can be seen on Figure 1 below:

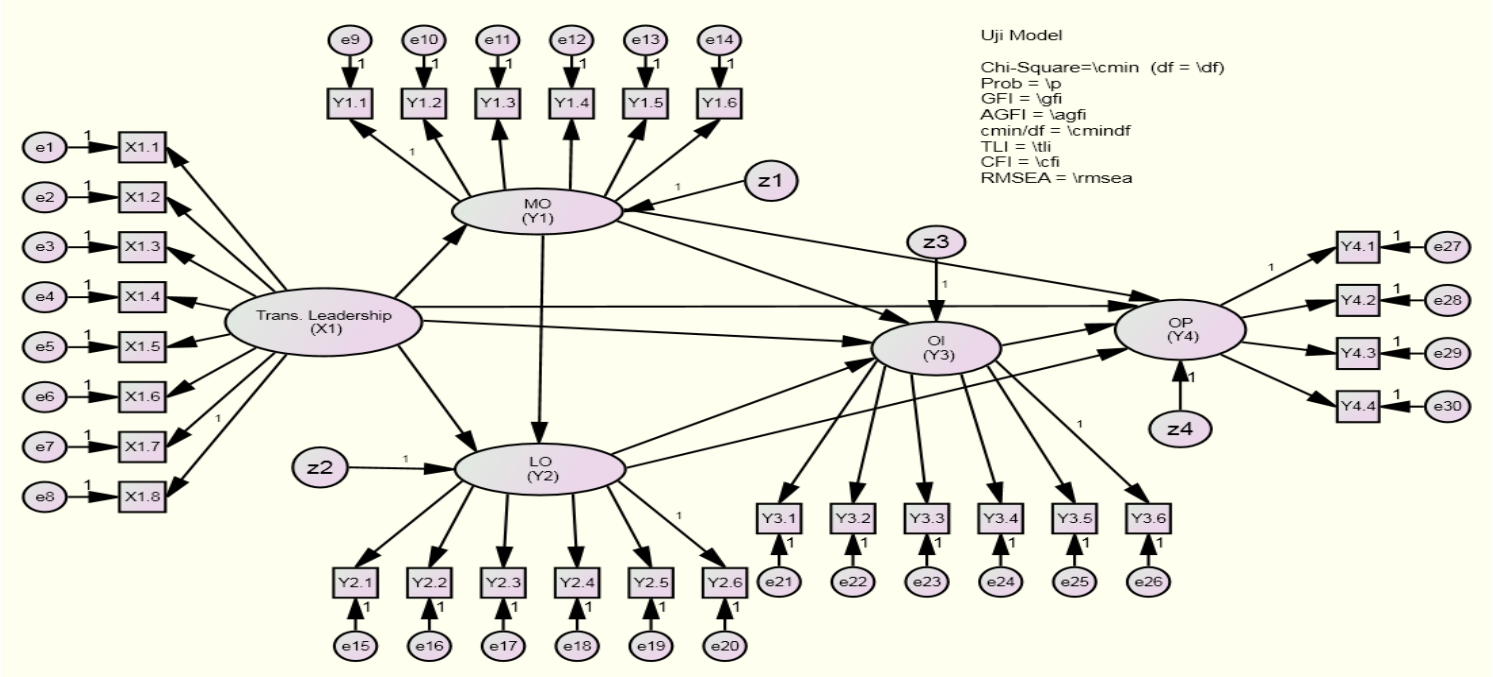

Figure 1. Research Hypotheses Model

Based on the hypotheses model above, hence, the hypotheses of the research are:

Hypothesis (1) there is a significant effect of transformational leadership on organization performance.

Hypothesis (2) there is a significant effect of transformational leadership on market orientation.

Hypothesis (3) there is a significant effect of transformational leadership on organization innovation.

Hypothesis (4) there is a significant effect of transformational leadership on learning orientation.

Hypothesis (5) there is a significant effect of market orientation on organization performance.

Hypothesis (6) there is a significant effect of market orientation on organization innovation.

Hypothesis (7) there is a significant effect of market orientation on learning orientation.

Hypothesis (8) there is a significant effect of learning orientation on organization innovation.

Hypothesis (9) there is a significant effect of learning orientation on organization performance.

Hypothesis (10) there is a significant effect of organization innovation on organization performance.

\section{SEM Assumptions Testing}

\section{Result}

There are several test performed in the assumptions testing of SEM, i.e. normality, linearity, and outlier. The assumption of multivariate normality is tested by using AMOS 18 software as seen in Appendix 5A. If the value of CR Multivariate data is smaller than $\mathrm{Z} 5 \%$, which is $1.96 \%$, the normal assumption of multivariate is fulfilled. However, if the value of CR Multivariate data is bigger than $1.96 \%$, the normal assumption of multivariate data is not fulfilled, which means the data is not normal. The value of CR Multivariate data is 0.772 (Appendix 5A), which is less than 1.96; therefore, the normal assumption of multivariate is fulfilled.

To examine the existence of an outlier, the researcher uses mahalanobis distance (Md). Mahalanobis distance is a distance measuring the distance of the central point of the "average" data from each observation point. Here, observation point is the questionnaire number of the respondent. The examination of outliers multivariate is performed by using mahalanobis criteria at $\mathrm{p}<0.001$ level. Mahalanobis distance is evaluated by using $\chi^{2}$ on the loose degree which is based on the number of indicators used. Here the number of indicators are 30 and the statistic table defines $\chi_{30}^{2}=53.301$. Based on the rules of decision-making, if Md is determined 
$>53.301$ from the observation point, the observation point is considered outlier. Meanwhile, if Md is determined $<53.301$ from the observation point, the observation point is not considered as outlier. From the Mahalanobis distance table (Appendix 5B), the farthest observation point is 86 with the $\mathrm{Md}=48.698$. Comparing to the value of $\chi_{30}^{2}=53.301$, the value of Md at point 86 is $<53.301$. Hence, it can be concluded that all data are not considered as outlier, and the assumption of data absence is fulfilled.

Testing of linearity assumption is done by applying Curve Fit method and is counted by using SPSS software. Parsimony principle is used as reference. When all models used as the basis of testing tend to be significant or non-significant, then, the model is said to be linear. The specifications of the models used as the basis of testing are linear model, quadratic, cubic, inversion, logarithmic, power, compound, growth and exponential.

\section{Goodness of Fit SEM}

The theoretical model of the research conceptual framework is considered fit when it is supported by empirical data. The testing results of goodness of fit overall model correspond to the SEM result analysis as seen on Table 1 below:

Tabel 1. The Testing Results of Goodness of Fit Overall Model

\begin{tabular}{|c|c|c|c|}
\hline Criteria & Cut-of value & Model Result & Description \\
\hline Chi square & small & 404.568 & Poor Model \\
\hline p-value & $\geq 0.05$ & 0.359 & Good Model \\
\hline CMIN/DF & $\leq 2.00$ & 1.024 & Pood Model \\
\hline GFI & $\geq 0.90$ & 0.819 & Poor Model Model \\
\hline AGFI & $\geq 0.90$ & 0.787 & Good Model \\
\hline TLI & $\geq 0.95$ & 0.993 & Good Model \\
\hline CFI & $\geq 0.95$ & 0.994 & Good Model \\
\hline RMSEA & $\leq 0.08$ & 0.015 & \\
\hline
\end{tabular}

The testing results of Goodness of Fit Overall based on table 1 above show the five criteria; p-value, CMIN/DF, TLI, CFI and RMSEA indicate a good model. According to Arbuckle and Wothke in Solimun (2009), the best criteria used as indication of the goodness of the model is Chi Square/DF that is less than 2, and RMSEA is below 0.08. In this study, the values of CMIN/DF and RMSEA have met the cut off value.

\section{Measurement Model}

Measurement model is measured from the loading factor (standardize coefficient) value of each indicator to the latent variable. Loading factor value indicates the weight of each indicator indicating the measure of each variable. Indicator with a big loading factor indicates that it acts as the most dominant variable measure. The result analysis of the confirmatory factors against the indicators of six variables can be seen on the table below.

Table 2. Testing Result of Measurement Model Variabel

\begin{tabular}{|c|c|c|}
\hline Variable/indicator & Standardize & P-Value \\
\hline \multicolumn{3}{|l|}{ Transformational Leadership $\left(\mathbf{X}_{1}\right)$ : } \\
\hline Giving Examples $\left(\mathrm{X}_{1.1}\right)$ & 0.753 & 0.000 \\
\hline Fostering Optimism $\left(\mathrm{X}_{1.2}\right)$ & 0.754 & 0.000 \\
\hline Giving Motivation $\left(\mathrm{X}_{1.3}\right)$ & 0.798 & 0.000 \\
\hline Providing Idea $\left(\mathrm{X}_{1.4}\right)$ & 0.811 & 0.000 \\
\hline Encouraging Innovation $\left(\mathrm{X}_{1.5}\right)$ & 0.733 & 0.000 \\
\hline Encouraging the involvement in Decision-Making $\left(\mathrm{X}_{1.6}\right)$ & 0.770 & 0.000 \\
\hline Providing Direction $\left(\mathrm{X}_{1.7}\right)$ & 0.695 & 0.000 \\
\hline Conferring Award $\left(\mathrm{X}_{1.8}\right)$ & 0.816 & Fix \\
\hline \multicolumn{3}{|l|}{ Market Orientation $\left(Y_{1}\right)$ : } \\
\hline Meeting Customer $\left(\mathrm{Y}_{1.1}\right)$ & 0.804 & Fix \\
\hline Conducting Market Survey $\left(\mathrm{Y}_{1.2}\right)$ & 0.808 & 0.000 \\
\hline Circulating Documents $\left(\mathrm{Y}_{1.3}\right)$ & 0.732 & 0.000 \\
\hline Disseminating Customer Satisfaction Data $\left(\mathrm{Y}_{1.4}\right)$ & 0.749 & 0.000 \\
\hline Reviewing Product Development $\left(\mathrm{Y}_{1.5}\right)$ & 0.745 & 0.000 \\
\hline Listening to Customer Complaints $\left(\mathrm{Y}_{1.6}\right)$ & 0.784 & 0.000 \\
\hline \multicolumn{3}{|l|}{ Learning Orientation $\left(\mathrm{Y}_{2}\right)$ : } \\
\hline Learning is considered as a shared-vision $\left(\mathrm{Y}_{2.1}\right)$ & 0.715 & 0.000 \\
\hline Having the commitment to achieve the goal $\left(\mathrm{Y}_{2.2}\right)$ & 0.702 & 0.000 \\
\hline $\begin{array}{l}\text { Openning for Self-Correction through sharing thoughts } \\
\left(\mathrm{Y}_{2.3}\right)\end{array}$ & 0.770 & 0.000 \\
\hline Recognizing Environment $\left(\mathrm{Y}_{2.4}\right)$ & 0.770 & 0.000 \\
\hline Analyzing Failure $\left(\mathrm{Y}_{2.5}\right)$ & 0.696 & 0.000 \\
\hline Using Method of Exchanging Experiences $\left(\mathrm{Y}_{2.6}\right)$ & 0.654 & Fix \\
\hline
\end{tabular}


The Effect Of Transformational Leadership On Market Orientation, Learning Orientation,

\begin{tabular}{|l|c|c|}
\hline \multicolumn{1}{|c|}{ Variable/indicator } & Standardize & P-Value \\
\hline Organization Innovation $\left(\mathbf{Y}_{3}\right):$ & & \\
\hline Improving Working Practices $\left(\mathrm{Y}_{3.1}\right)$ & 0.795 & 0.000 \\
\hline Training Employees routinely $\left(\mathrm{Y}_{3.2}\right)$ & 0.663 & 0.000 \\
\hline Creating New Services $\left(\mathrm{Y}_{3.3}\right)$ & 0.666 & 0.000 \\
\hline Creating Modification of Services $\left(\mathrm{Y}_{3.4}\right)$ & 0.735 & 0.000 \\
\hline Developing New Ideas $\left(\mathrm{Y}_{3.5}\right)$ & 0.741 & 0.000 \\
\hline Encouraging Initiatives $\left(\mathrm{Y}_{3.6}\right)$ & 0.746 & Fix \\
\hline Organization Performance $\left(\mathbf{Y}_{\mathbf{4}}\right):$ & & Fix \\
\hline The Decreasing Number of Complaints $\left(\mathrm{Y}_{4.1}\right)$ & 0.616 & 0.000 \\
\hline The Increasing Number of Room Occupations $\left(\mathrm{Y}_{4.2}\right)$ & 0.620 & 0.000 \\
\hline The Increasing Number of Market Share $\left(\mathrm{Y}_{4.3}\right)$ & 0.797 & 0.000 \\
\hline The Increasing Number of New Customers $\left(\mathrm{Y}_{4.4}\right)$ & 0.735 & \\
\hline
\end{tabular}

Description: significant ( $\mathrm{p}$-value $<0,05$ )

\section{Structural Model}

In this structural model, ten hypotheses regarding the relationship among variables are examined (direct effect). Below is the complete testing result of the relationship among research variables.

Table 3. Structural Model of SEM Result: Direct Effect

\begin{tabular}{|c|c|c|c|}
\hline $\begin{array}{l}\text { Hypothesis } \\
\text { Number }\end{array}$ & Relationship among Variables & Standardize & P-value \\
\hline 1 & $\begin{array}{l}\text { Transformational Leadership }\left(\mathrm{X}_{1}\right) \text { towards Organization } \\
\text { Performance }\left(\mathrm{Y}_{4}\right)\end{array}$ & 0.139 & $0.222^{\mathrm{ns}}$ \\
\hline 2 & $\begin{array}{l}\text { Transformational Leadership }\left(\mathrm{X}_{1}\right) \text { towards Market } \\
\text { Orientation }\left(\mathrm{Y}_{1}\right)\end{array}$ & 0.252 & $0.018^{*}$ \\
\hline 3 & $\begin{array}{l}\text { Transformational Leadership }\left(\mathrm{X}_{1}\right) \text { towards Organization } \\
\text { Innovation }\left(\mathrm{Y}_{3}\right)\end{array}$ & 0.249 & $0.018^{*}$ \\
\hline 4 & $\begin{array}{l}\text { Transformational Leadership }\left(\mathrm{X}_{1}\right) \text { towards Learning } \\
\text { Orientation }\left(\mathrm{Y}_{2}\right)\end{array}$ & 0.294 & $0.008 *$ \\
\hline 5 & $\begin{array}{l}\text { Market Orientation }\left(\mathrm{Y}_{1}\right) \text { towards Organization } \\
\text { Performance }\left(\mathrm{Y}_{4}\right)\end{array}$ & 0.17 & $0.126^{\mathrm{ns}}$ \\
\hline 6 & $\begin{array}{l}\text { Market Orientation }\left(\mathrm{Y}_{1}\right) \text { towards Organization Innovation } \\
\left(\mathrm{Y}_{3}\right)\end{array}$ & 0.257 & $0.013^{*}$ \\
\hline 7 & $\begin{array}{l}\text { Market Orientation }\left(\mathrm{Y}_{1}\right) \text { towards Learning Orientation } \\
\left(\mathrm{Y}_{2}\right)\end{array}$ & 0.166 & $0.130^{\mathrm{ns}}$ \\
\hline 8 & $\begin{array}{l}\text { Learning Orientation }\left(\mathrm{Y}_{2}\right) \text { towards Organization } \\
\text { Innovation }\left(\mathrm{Y}_{3}\right)\end{array}$ & 0.26 & $0.020 *$ \\
\hline 9 & $\begin{array}{l}\text { Learning Orientation }\left(\mathrm{Y}_{2}\right) \text { towards Organization } \\
\text { Performance }\left(\mathrm{Y}_{4}\right)\end{array}$ & -0.011 & $0.921^{\mathrm{ns}}$ \\
\hline 10 & $\begin{array}{l}\text { Organization Innovation }\left(\mathrm{Y}_{3}\right) \text { towards Organization } \\
\text { Performance }\left(\mathrm{Y}_{4}\right)\end{array}$ & 0.427 & $0.003^{*}$ \\
\hline
\end{tabular}

Description: the mark * indicates significant, and the mark ${ }^{\text {ns }}$ indicates nonsignificant

The Result of the Structural Model is seen on Figure 2 below:

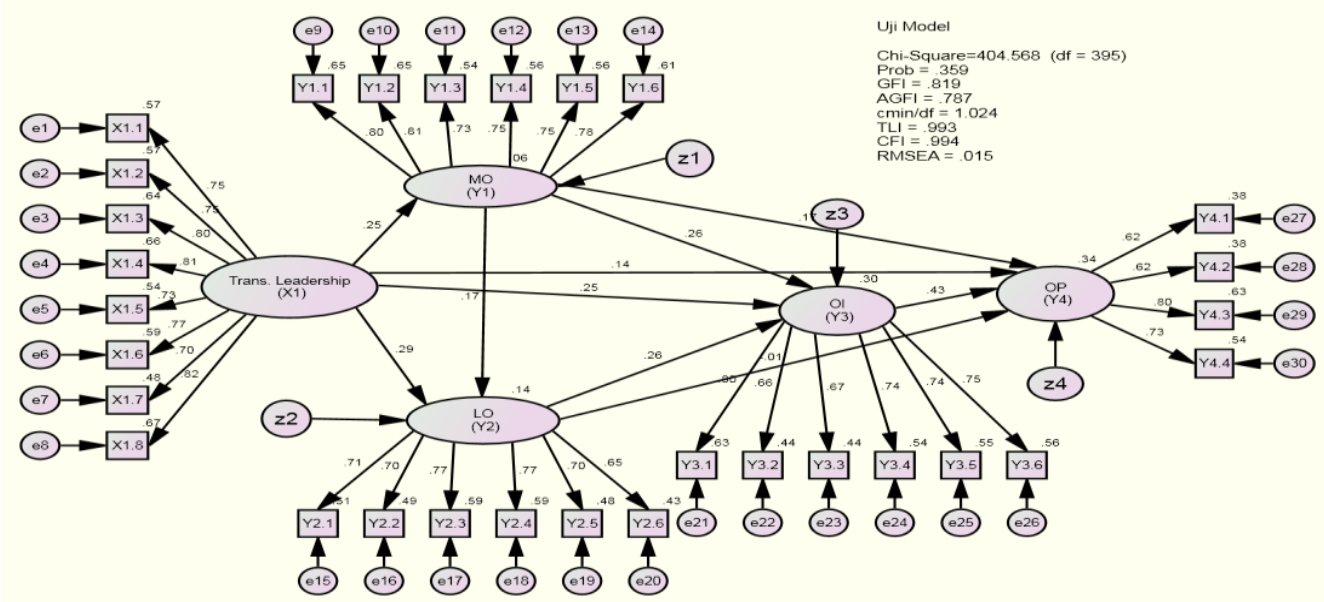

Figure 2. The Diagram of SEM Analysis Result Lines 
Based on the data on Table 3 and Figure 2 above, the results of the structural model test are as follows:

1. There is a non-significant effect of Transformational Leadership on Organization Performance. It can be seen from the p-value of $0.222>$ alpha/error rate $(0.05)$. It means, regardless the value of Transformational Leadership, it will not affect the value of Organization Performance.

2. There is a significant effect of Transformational Leadership on Market Orientation. It can be seen from the p-value of $0.018<$ alpha/error rate $(0.05)$. The positive coefficient indicates that the relationship between Transformational Leadership and Market Orientation is in line. It means, the better value of Transformational Leadership is parallel with the better Market Orientation value.

3. There is a significant effect of Transformational Leadership on Organization Innovation. It can be seen from the p-value of $0.018<$ alpha/error rate $(0.05)$. The positive coefficient indicates that the relationship between Transformational Leadership and Organization Innovation is in line. It means, the better value of Transformational Leadership is parallel with the Organization Innovation value.

4. There is a significant effect of Transformational Leadership on Learning Orientation. It can be seen from the p-value of $0.008<$ alpha/error rate $(0.05)$. The positive coefficient indicates that the relationship between Transformational Leadership and Learning Orientation is in line. It means, the better value of Transformational Leadership is parallel with the Learning Orientation value.

5. There is a non-significant effect of Market Orientation on Organization Performance. It can be seen from the $\mathrm{p}$-value of $0.126>$ alpha/error rate (0.005). It means, regardless the value of Market Orientation, it will not affect the value of Organization Performance.

6. There is a significant effect of Market Orientation on Organization Innovation. It can be seen from the pvalue of $0.013<$ alpha/error rate $(0.005)$. The positive coefficient indicates that the relationship between Market Orientation and Organization Innovation is in line. It means, the better value of Market Orientation is parallel with the Organization Innovation value.

7. There is a non-significant effect of Market Orientation on Learning Orientation. It can be seen from the pvalue of $0.130>$ alpha/error rate (0.05). It means, regardless the value of Market Orientation, it will not affect the value of Learning Orientation.

8. There is a significant effect of Learning Orientation on Organization Innovation. It can be seen from the pvalue of $0.020<$ alpha/error rate $(0.05)$. The positive coefficient indicates that the relationship between Learning Orientation and Organization Innovation is in line. It means, the better value of Learning Orientation is parallel with the Organization Innovation.

9. There is a non-significant effect of Learning Orientation on Organization Performance. It can be seen from the p-value of $0.921>$ alpha/error rate $(0.05)$. It means, regardless the value of Learning Orientation, it will not affect the value of Organization Performance.

10. There is a significant effect of Organization Innovation on Organization Performance. It can be seen from the p-value of $0.003<$ alpha/error rate $(0.05)$. The positive coefficient indicates that the relationship between Organization Innovation and Organization Performance is in line. It means, the better value of Organization Innovation is parallel with the Organization Performance value.

This study elaborates the previous research of Gowen et al. (2009), Ensley et al. (2006), Meindl et al. (1985), and Pfeffer (1977) (Hypothesis 1); Felton (1959), Harris (1998), Chaganti and Sambharya (1987), Messikomer (1987), Wonget et al. (1989), Harris and Piercy (1999), Harris and Ogbonna (2001), Najib (2003) (Hypothesis 2); Mumford et al. (2002), Amabile (1998), Yukl (2001), Jung (2001), Schein (1992), Bass and Avolio (1997), Scott and Bruce (1994), Kanter (1983), McDonough (2000), Manz et al. (1989), Tushman and Nadler (1986), Harbone and Johne (2003), Sethi (2000), Jung et al. (2003), Garcia-Morales et al. (2008/1), Garcia-Morales et al. (2008/2), Gumusluoglu and Ilsev (2009/1), Jung et al. (2004), Garcia-Morales et al. (2006), Gumusluoglu and Ilsev (2009/2), Senge et al. (1994) (Hypothesis 3); Coad and Berry (1998) (Hypothesis 4); Jaworski and Kohli (1993), Selnes et al. (1996), Pelham (1997), Deshpande et al. (2000), Harris (2002), Han et al. (1998) (Hypothesis 5); Han et al. (1998), Hult et al. (2004), Sandvik and Sandvik (2003), Kirca et al. (2005), Wu et al. (2008), Han et al. (1998), Jimenez-Jimenez and Valle (2008), Lin et al. (2008), Kirca et al. (2005), Mavondo et al. (2005), Tajeddini et al. (2006), Lado (2001), Agarwal et al. (2003) (Hypothesis 6); Lee and Tsai (2005), Akgun et al. (2007), Rhee et al. (2009), Calantone et al. (2002), Sinkula et al. (1997), Wu et al. (2008), Lin et al. (2008), Farrell (1999), Garrido and Camarero (2010), Liu et al. (2002), Hult et al. (2004), Keskin (2006), Garcia-Morales et al. (2006) (Hypothesis 8); Wu et al. (2008), Farrell et al. (2008), Garrido and Camarero (2010), Baker and Sinkula (1999), Slater and Narver (1995), Droge, Vickery and Markland (1995) (Hypothesis 9); and Garcia-Morales et al. (2008), Hurley and Hult (1998), Loof and Heshmati (2002), Andneels and Kleinschmidt (2001), Wu et al. (2008), Li-An Ho (2011), Camison and Lopez (2010), Correa et al. (2007), Damanpour (1991), Gopalakrishnan (2000), Rhee (2009), Calantone et al. (2002), GarciaMorales et al. (2006), Keskin (2006), Lee and Tsai (2005), Garcia-Morales and Llorens-Montes (2006), Han et 
al. (1998), Jimenez-Jimenez and Valle (2008), Lin et al. (2008), Garrido and Camarero (2010), Agarwal et al. (2003), Subin-Im and Workman (2004), Hurley et al. (2003), Porter (1990), Damanpour and Evan (1984), Damanpour, Szabat, and Evan (1989), serta Zahra, de Belardino, and Boxx (1988) (Hypothesis 10).

\section{Conclusion And Recommendation}

Several conclusions of this study involve (1) Transformational Leadership does not have a significant effect on Organization Performance, (2) Transformational Leadership has a significant effect on Market Orientation, (3) Transformational Leadership has a significant effect on Organization Innovation, (4) Transformational Leadership has a significant effect on Learning Orientation, (5) Market Orientation does not have a significant effect on Organization Performance, (6) Market Orientation has a significant effect on Organization Innovation, (7) Market Orientation does not have a significant effect on Learning Orientation, (8) Learning Orientation has a significant effect on Organization Innovation, (9) Learning Orientation does not have a significant effect on Organization Performance and (10) Organization Innovation has a significant effect on Organization Performance. The study presents recommendations to the following parties (1) Future Researcher: future researcher can develop similar or different model by using several or all dimensions/indicators of learning orientation and organization performance variables. The same research model can also be developed by using different research object; (2) Owners of Star-Rated Hotels: The owners of starrated hotels should maintain the principles of transformational leadership, increase market orientation level, enhance learning orientation, improve organization innovation and elevate organization performance; (3) Local Government: Local Government should supervise the star-rated hotels and create conducive atmosphere in promoting tourism.

\section{References}

[1] Agarwal, S., Erramilli, K., Dev. Chekitan, S., 2003, Market Oriented and Performance in Service Firms: Role of Innovation, Journal of Services Marketing, Vol. 17, No. 1, pp.68-82

[2] Akgun, A.E., Keskin, H., Byrne, J.C., Aren, S., 2007, Emotional and learning capability and their impact on product innovativeness and firm performance, Technovation 27, 501-513

[3] Amabile, T.M., 1998, How to kill creativity, Harvard Business Review, 76(9), pp. 77-87

[4] Avlonitis, G.J. and Gounaris, S., 1997, Marketing orientation and company performance, Industrial Marketing Management, Vol. 26, No. 5, pp. $385-402$

[5] Avolio, BJ., and Bass, BM., 2002, Developing potential across a full range of leadership: cases on transactional and transformational leadership, Mahwah, NJ: Lawrence Erlbaum Associates, San Diego

[6] Baker, Willam. E. And Sinkula, James. M., 1999, Learning Orientation, Market Orientation, and Innovation: Integrating and Extending Models of Organizational Performance, Journal Market Focused Management, Vol. 4, No. 4, pp. 295-308

[7] Baker, W.E., Sinkula, J.M., 1999, The synergistic effect of market orientation on organizational performance, Journal of the Academy of Marketing Science, 27, 411-427

[8] Baker, W.E., Sinkula, J.M., 2002, Market orientation, learning orientation and product innovation: delving into the organization's black box, Journal of Market Focused Management, 5, 5-23.

[9] Baker, William. E. And Sinkula, James. M., 2005, Market Orientation and the New Product, Paradox, Journal Product Development and Management Association, Vol. 22, No. 6, pp. 483-502

[10] Bass B.M., and Avolio, B.J., 1993, Transformational Leadership and Organizational Culture, Public Administration Querterly, 17(1): 112-17

[11] Bass, B. M., \& Avolio, B. J., 1997, Full-range of leadership development: Manual for the Multifactor Leadership Questionnaire, Palo Alto, CA: Mind Garden

[12] Bell, S.J., Whitwell, G.J., Lukas, B.A., 2002, Schools of though in organizational learning, Journal of the Academy of Marketing Science, 30 (1), 70-86

[13] Bhuian, S.N., 1998, An Empirical Examination of Market Orientation in Saudi Arabian Manufacturing Companies, Journal of Business Research, Vol. 11, No. 5, pp. 317-338

[14] Burns, James MacGregor, 1978, Transactional and Transforming Leadership: Leadership. In Leading Organizations Perspectives for a New Era, Gill Robinson Hickman (editor). Sage Publications. Inc.

[15] Calantone, R.J., Cavusgil, S.T., Zhao, Y., 2002, Learning orientation, firm innovation capability, and firm performance, Industrial Marketing Management, 31, 515-524

[16] Camison, C. and Lopez, A.V., 2010, An examination of the relationship between manufacturing flexibility and firm performance: the mediating role of innovation, International Journal of Operations \& Production Management, Vol. 30, No. 8, pp. 853-78

[17] Castro, Carmen B. Amario Enrique, M. Rio Maria Elena Sanchez D., 2005, Consequences of Market Orientation for Customers and Employees, Vol. 39, No. 5/6, pp. 646-673

[18] Chaganti, R. and Sambharya, R., 1987, Strategic orientation and characteristics of top management, Strategic Management Journal, Vol. 8, pp. 393-401

[19\} Coad, Alan F. and Berry, Anthony J., 1998, Transformational leadership and learning orientation, Leadership \& Organization Development Journal, 19/3, 164-172

[20] Correa, J. Alberto Aragon, Garcia-Morales, Victor J., and Cordon-Pozo, Eulogio, 2007, Leadership and organizational learning's role on innovation and performance: Lessons from Spain, Industrial Marketing Management, 36, 349-359

[21] Damanik, Janianton, 2011, Kecenderungan Baru Pariwisata Global Sebagai Tantang and Agenda Penelitian, Makalah Seminar Nasional: Trend Penelitian Administrasi Bisnis and Manajemen, FIA, Universitas Brawijaya, Malang, 29 Oktober

[22] Damanpour, F., 1991, Organizational innovation: A meta-analysis of effects of determinants and moderators, Academy of Management Journal, 34: 555-590

[23] Damanpour, F. And Evan, WM., 1984, Organizational Innovation and Performance: The Problem of Organizational Lag, Administrative Science Quarterly, Vol. 29, September, pp. 392-409 
[24] Damanpour, F., Szabat, K.A. and Evan, WM., 1989, The Relationship between Type of Innovation and Organizational Performance, Journal of Management Science, Vol. 26, November, pp. 587-607

[25] Andneels, E. and Kleinschmidt, E.J., 2001, Product innovativeness form the firm's perspective: its dimensions and their relation with project selection and performance, The Journal of Product Innovation Management, Vol. 18, pp. 357-73

[26] Darroch, Jenny, 2005, Knowledge Management, Innovation and Firm Performance, Journal of Knowledge Management, Vol. 9, No. 3, pp. 101-115

[27] DeGeus, A., 1988, Planning as Learning, Harvard Business Review, Vol. 66, March-April, pp. 70-74

[28] Deshpande, R. and Farley, J.U. and Webster, F.E., 2000, Triad Lessons: Generalizing Results on High Performance Firms in Five Business-Business Markets, International Journal of Research in Marketing, Vol. 17, No. 4, pp. 353-362

[29] Dickson, P.R., 1992, Toward a General Theory of Competitive Rationality, Journal of Marketing, Vol. 56, No.1, pp. 69-83

[30] Elencov, S. Detelin., 2002, Effects of Leadership on Organizational Performance in Business Companies, Journal of Business Research, Vol 43 (2), pp.467480

[31] Ensley, Michael D., Pearce, Craig L., and Hmieleski, Keith M., 2006, The moderating effect of environmental dynamism on the relationship between entrepreneur leadership behavior and new venture performance, Journal of Business Venturing, 21, 243-263

[32] Farrell, Mark, A., 2000, Developing a Market Oriented Learning Organization, Australian Journal Management, Vol. 25, No. 2, pp. 201-217

[33] Garcia-Morales, Victor J., Matias-Reche, Fernando and Hurtado-Torres, Nuria, 2008/1, Influence of transformational leadership on organizational innovation and performance depending on the level of organizational learning in the pharmaceutical sector, Journal of Organizational Change Management, Vol. 21, No. 2, pp. 188-212

[34] Garcia-Morales, Victor J. and Llorens-Montes, Fransisco, 2006, Antecedents and consequences of organizational innovation and organizational learning in entrepreneurship, Industrial Management \& Data Systems, Vol. 106, No. 1, pp. 21-42

[35] Garcia-Morales, Victor J. and Llorens-Montes, Fransisco, and Verdu-Jover, Antonio J., 2008/2, The Effects of Transformational Leadership on Organizational Performance through Knowledge and Innovation, British Journal of Management, Vol. 19, 299-319

[36] Garrido, M. Jose and Camarero, Carmen, 2010, Assessing the impact of organizational learning and innovation on performance in cultural organizations, International Journal of Nonprofits and Voluntary Sector Marketing, pp. 215-232

[37] Garvin, David A., 1993, Building A Learning Organization, Harvard Bussiness Review, p. 78-91

[38] Gowen, Charles R, Henagan, Stephanie C, and McFadden, Kathleen L, 2009, Knowledge management as a mediator for the efficacy of transformational leadership and quality management initiatives in U.S. health care, Health Care Management Review, 34 (2), 129-140

[39] Gopalakrishnan, S., 2000, Unraveling the links between dimensions of innovation and organizational performance, The Journal of High Technology Management Research, 11 (1), 137-153

[40] Gumusluoglu, Lale and Ilsev, Arzu, 2009, Transformational leadership, creativity, and organizational innovation, Journal of Business Research, 62, 461-473

[41] Gumusluoglu, Lale and Ilsev, Arzu, 2009, Transformational Leadership and Organizational Innovation: The Roles of Internal and External Support for Innovation, Bilkent University, Ankara, Tukey

[42] Han, J.K., Kim, N., and Srivastava, R., 1998, Market Orientation and Organizational Performance: Is Innovation A Missing Link?, Journal of Marketing, Vol. 62, October, pp.30-45

[43] Harbone, P., \& Johne, A., 2003, Creating project climate for successful product innovation, European Journal of Innovation Management, 6 (2), 118-132

[44] Harris, L.C and Ogbonna, E., 2001, Strategic Human Resource Management, Market Orientation and Organizational Performance, Journal of Business Research, Vol. 51, No. 2, pp. 157-166

[45] Harris, L.C and Ogbonna, E., 2001, Leadership style and market orientation: an empirical study, European Journal of Marketing, Vol. 35, No. 5/6, pp. 744-764

[46] Harris, L.C and Piercy, N., 1999, Management Behavior and Barriers to Market Orientation in Retailling Companies, The Journal of Service Marketing, Vol. 13, No. 2, pp. 113-131

[47] Hult, G.T.M., Hurley, R.F., Knight, G.A., 2004, Innovativeness: its antecedents and impact on business performance, Industrial Marketing Management, 33, 429-438

[48] Hunt, S.D. and Morgan, R.M., 1995, The Comparative Advantage Theory of Competition, Journal of Marketing, Vol. 59, No. 2, pp. $1-15$

[49] Hurley, Robert F. And Hult, Thomas M., 1998, Innovation, Market Orientation, and Organizational Learning: An Integration and Empirical Examination, Journal Marketing, Vol. 62, No. 3, pp. 42-54

[50] Im, Subin and Workman Jr, John, P., 2004, Market Orientation, Creativity, and New Product Performance In High Technology Firms, Journal of Marketing, Vol. 68, April, pp. 114-132

[51] Jain, Sanjay, K. and Bhutia, Manju, 2007, Market Orientation and Business Performance: The Case of Indian Manufacturing Firm, The Journal of Business Perspective, Vol. 11, No. 1, January-March, pp. 15-33

[52] Jaworski, B.J. and Kohli, A.K., 1993, Market Orientation, Antecedents and Consequences, Journal of Marketing, Vol. 57, July, pp. $53-70$

[53] Jimenez-Jimenez, Andiel and Valle, Raquel Sanz, 2008, Fostering innovation: The role of market orientation and organizational learning, European Journal of Innovation Management, Vol. 11, No. 3, pp. 389-412

[54] Jung, D., 2001, Transformational and transactional leadership and their e ffects on creativity in groups, Creativity Research Journal, 13: 185-195

[55] Jung, D, Chow, Chee and Wu, Anne, 2003, The role of transformational leadership in enhancing organizational innovation: Hypotheses and some preliminary findings, The Leadership Quarterly, 14, pp. 525-544

[56] Jung, D, Chow, Chee and Wu, Anne, 2003, Towards Understanding the Direct and Indirect Effects of Transformational Leadership on Firm Innovation, San Diego State University

[57] Kanter, R. M., 1983, The Change Masters, New York: Simon \& Schuster

[58] Keskin, H., 2006, Market orientation, learning orientation, and innovation capabilities in SMEs, European Journal of Innovation Management, 9 (4), 396-417

[59] Kirca, A., H. Jayachandran, S., and Bearden, W.O., 2005, Market Orientation: A Meta-Analytic Review and Assessment of Its Antecedents and Impact on Performance, Journal of Marketing, Vol. 69, April, pp. 24-41

[60] Kohli, A. And Jaworski, B., 1990, Market Orientation: The Construct, Research Proposition and Managerial Implication, Jornal of Marketing, Vol. 54, April, pp.1-18

[61] Kurtaintene, Jolita, 2005, Marketing Orientation in The European Union Mobile Telecommunication Market, Marketing Intelligence and Planning, Vol. 23, No. 1, pp. 104-113 
[62] Lado, Nora and Olivares, Albert M., 2001, Exploring The Link Between Market Orientation and Innovation in The European and US Insurance Markets, International Marketing Review, Vol. 18, No. 2, pp. 130-144

[63] Lawton, L. and Parasuraman, A., 1980, The Impact of Marketing Concept on New Product Planning, Journal of Marketing, Vol. 44, No. 1 , pp. $19-25$

[64] Lee, T.S. and Tsai, H.J., 2005, The effects of business operation mode on market orientation, learning orientation and innovativeness, Industrial Management \& Data Systems, Vol. 105, No. 3, pp. 325-48

[65] Li-An Ho, 2011, Meditation, learning, organizational innovation and performance, Industrial Management \& Data Systems, Vol. 111 , No. 1, pp. 113-131

[66] Lin, Chien Huang, Peng, Ching Huai, and Kao, Andny T., 2008, The innovativeness effect of market orientation and learning oreintation on business performance, International Journal of Manpower, Vol. 29, No. 8, pp. 752-772

[67] Liu, S.S., Luo, X., Shi, Y., 2002, Integrating customer orientation in organizations-intransition: an empirical study, International Journal of Research in Marketing, 19, 367-382

[68] Loof, H. and Heshmati, A., 2002, Knowledge capital and performance heterogeneity: a firm-level innovation study, International Journal of Production Economics, Vol. 76, pp. 61-85

[69] Lukas, B.A. and O.C. Ferrell, 2000, The Effect of Market Orientation on Product Innovation, Journal of Academy of Marketing Science, Vol. 28, No. 2, pp. 239-247

[70] Lussier, Robert N., and Christopher F. Achua., 2001, Leadership: Theory, Application, Skill Development, South-Western College Publishing, United States

[71] Manz, Charles C., and Henry, P. Sims Jr., 2001, The New Super Leadership: Leading Others to Lead Themselves, Berrett-Koehler Publishers, Inc., San Francisco

[72] Mavondo, Felix, T. Chimhanzi, Jacqueline, Stewart, Jillian, 2005, Learning Orientation and Market Orientation: Relationship with Innovation, Human Resource Practices and Performance, European Journal of Marketing, Vol. 39, No. 11/12, pp. 1235-1263

[73] McDonough, E.F., 2000, Investigation on factors contributing to the success of cross-functional teams, Journal of Product Innovation Management, Vol. 17, pp. 221-35

[74] Messikomer,E.E., 1987, Marketing changes the corporate culture: a company study, The Journal of Business and Industrial Marketing, Vol. 2, No.4, pp. 53-58

[75] Morgan, R.E. Katsikeas, C.S and Adu, Kwaku, A., 1998, Market Orientation and Organizational Learning Capabilities, Journal of Marketing Management, Vol. 14, No. 4/5, pp. 353-381

[76] Mumford, M.D., Scott, G.M., Gaddis, B., \& Strange, J.M., 2002, Leading creative people: Orchestrating expertis e and relationships, Leadership Quarterly, 13: 705-750

[77] Najib, Mukhamad, 2003, Hubungan Antara Gaya Kepemimpinan, Orientasi Pasar and Kinerja Usaha Kecil and Menengah (UKM) di Indonesia, Tesis, Program Studi Ilmu Manajemen, Universitas Indonesia, Jakarta

[78] Narver, J.C. and Slater, S.F., 1990, The Effect of A Market Orientation on Business Profitability, Journal of Marketing Research, Vol. 54, October, pp. 20-35

[79] Page, S. J., 2007, Tourism Management: Managing for Change, Oxford, Butterworth, Heinemann

[80] Pelham, A.M., 1997, Mediating Influences on the Relationship between Market Orientation and Profitability in Small Industrial Firms, Journal of Business Research, Vol. 45, No. 1, pp. 33-46

[81] Porter, M.E., 1985, Competitive Advantage, Creating and Sustaining Superior Performance, Free Press, New York

[82] Rhee, Jaehoo, Park, Taekyung, and Lee, Do Hyung, 2009, Drivers of innovativeness and performance for innovative SMEs in South Korea: Mediation of learning oreintation, Elsevier

[83] Schein, E. H., 1992, Organizational culture and leadership, San Francisco, CA: Jossey-Bass

[84] Scott, S.G., \& Bruce, R.A., 1994, Determinants of innovative behavior: A path model of individual innovation in the workplace, Academy of Management Journal, 37: 580-607

[85] Selnes, F., Jaworski, B.J. Kohli, A.K., 1996, Market Orientation in United States and Scandinavian Companies: A Cross Cultura1 Study, Scandinavian Management Journal, Vol. 12, No. 2, pp. 139-157

[86] Senge, P.M, 1994, The Fifth Discipline Fieldbook, Doubleday \& Currency, NY

[87] Sethi, R., 2000, New product quality and product development teams, Journal of Marketing, 64, 1-14

[88] Siguaw JA, Simpson PM, and Baker TL., 1998, Effects of supplier market orientation on distributor market orientation and the channel relationship: the distributor perspective, Journal of Marketing, 62 (July): 99-111

[89] Sinkula, J.M., Bake, W., Noordewier, T.G., 1997, A framework for market-based organizational learning: linking values, knowledge and behavior, Journal of the Academy of Marketing Science, 25 (4), 305-318

[90] Slater, S.F., and Narver, J.C., 1995, Market Orientation and The Learning Organization, Journal of Marketing, Vol. 59, July, pp. 63-74

[91] Solimun, 2007, Memahami Metode Kuantitatif Mutakhir Structural Equation Modeling \& Partial Least Square, Program Studi Statistika FMIPA Universitas Brawijaya Malang

[92] Stata, Ray, 1989, Organizational Learning: The Key to Management Innovation, Sloan Management Review, p.63-74

[93] Tajeddini, Kayhan, Trueman, Myfanwy, Larsen, Gretchen, 2006, Examining The Effect of Market Orientation on Innovativeness, Journal of Marketing Management, Vol. 22, No. 5/6, pp 529-551

[94] Tushman, M.L. and Nadler, D.A., 1986, Organizing for innovation, California Management Review, Vol. 28, No. 3, pp. 74-92

[95] Vazquez, Rudolfo, Santos, Maria, L., and Alvarez, Lis, I., 2001, Market Orientation, Innovation, and Competitive Strategies in Industrial Firm, Journal of Strategic Marketing, Vol. 9, No. 2, pp. 69-90

[96] Verhess, Frans J.H.M and Meulenberg Matthew T.G., 2004, Market Orientation, Innovativeness, Product Innovation, and Performance In Small Firms, Journal of Small Business Management, Vol. 42, No. 2, pp. 134-154

[97] Wong, V., Saunders, J. and Doyle, P., 1989, The barriers to achieving stronger market orientation in British companies: an exploratory study, Proceedings of the 22nd Marketing Education Group Conference, pp. 35-64

[98] Wu, Wann Yih, Lin, Chin Ho and Tsai, Hsin Ju, 2008, The Impacts of Market Orientation, Learning Orientation, Innovation on Organizational Performance, National Cheng Kung University

[99] Yukl, Gary A., 2009, Kepemimpinan dalam Organisasi, (Edisi Bahasa Indonesia), PT. Indeks, Jakarta

[100] Yukl, G., 2001, Leadership in organizations, Upper Saddle River, NJ: Prentice-Hall

[101] Zahra, S.A., De Belardino, S. And Boxx, W.R., 1998, Organizational Innovation: Its Correlates and It Implications for Financial Performance, International Journal of Management, Vol. 5, June, pp. 133-142 